\title{
Flow cytometry and start codon targeted (SCOT) genetic fidelity assessment of regenerated plantlets in Tylophora indica (Burm.f.) Merrill
}

\author{
Jyoti Mamgain ${ }^{1} \cdot$ A. Mujib ${ }^{1}$ (D) Bushra Ejaz ${ }^{1} \cdot$ Basit Gulzar $^{1} \cdot$ Moien Qadir Malik $^{1} \cdot$ Rukaya Syeed $^{1}$
}

Received: 23 November 2021 / Accepted: 11 February 2022 / Published online: 28 February 2022

(c) The Author(s), under exclusive licence to Springer Nature B.V. 2022

\begin{abstract}
Tylophora indica (Burm.f.) Merrill. is a pharmacologically important plant, popular for alkaloidal and non-alkaloidal richness. Large scale propagation of $T$. indica is difficult in the wild as the seeds are small and the frequency of germination is very poor. In the present study, the genome size estimation of in vitro regenerated (indirect, direct and somatic embryo mediated) T. indica was made by flow cytometric method. Clonal fidelity of the regenerants was assessed using a start codon targeted (SCoT) molecular marker. Initially, the explants were inoculated on Murashige and Skoog basal medium supplemented with various concentrations of plant growth regulators like 2,4-dichlorophenoxy acetic acid (2,4-D), Kinetin, 6-benzyl amino purine (BAP) and 1-naphthalene acetic acid either singly or in combinations. The highest callus induction frequency (87.75\%) was obtained in 6.7 $\mu \mathrm{M}$ 2,4-D added MS medium which metamorphosed into progressive stages (globular, heart, torpedo, and cotyledonary) of embryos. Mature and healthy somatic embryos efficiently germinated into plantlets on $8.8 \mu \mathrm{M} \mathrm{BAP}+1.4 \mu \mathrm{M} \mathrm{GA}_{3}$ enriched MS medium. Histological and scanning electron microscopic study confirmed the above developing stages. The regenerated shoots were rooted best in $2.45 \mu \mathrm{M}$ Indole-3-butyric acid supplemented solid MS medium. The plants were hardened and acclimatized with $90 \%$ survivability. The flow cytometric 2C DNA content of indirect, direct and somatic embryo derived plants was $1.896 \mathrm{pg}, 1.940 \mathrm{pg}$ and $1.926 \mathrm{pg}$ respectively, very similar to the mother plant (1.928 pg). SCoT marker generated a high percentage of monomorphic bands (94\%) revealing similarity with the mother plant, thus ensuring genetic fidelity. To the best of our knowledge, this is perhaps the first ever report of 2C DNA content estimation and SCoT marker based genetic homogeneity study in T. indica.
\end{abstract}

\section{Key message}

An efficient regeneration method has been developed in T. indica. Histology and SEM indicated somatic embryogenesis based morphogenesis. $2 \mathrm{C}$ genome size and SCoT marker revealed genetic homogeneity of the regenerated population.

Keywords 2C DNA $\cdot$ In vitro proliferation $\cdot$ Somatic embryogenesis $\cdot$ Organogenesis $\cdot$ Micropropagation $\cdot$ Histology $\cdot$ SEM

$\begin{array}{ll}\text { Abbreviations } \\ \text { BAP } & \text { 6-Benzylamino purine } \\ \text { 2, 4-D } & \text { 2, 4-Dichlorophenoxy acetic acid } \\ \text { IAA } & \text { Indole-3-acetic acid } \\ \text { IBA } & \text { Indole-3-butyric acid } \\ \text { KN } & \text { Kinetin }\end{array}$

Communicated by Ali R. Alan.

A. Mujib

amujib3@yahoo.co.in

1 Cellular Differentiation and Molecular Genetics Section, Department of Botany, Jamia Hamdard, New Delhi, India
NAA $\alpha$-Naphthalene acetic acid

PGRs Plant growth regulators

SEM Scanning electron microscopy

SCoT Start codon targeted

FCM Flow cytometry

RAPD Random amplified polymorphic DNA

\section{Introduction}

About $75 \%$ of the developing nations depend on conventional medications of which $25 \%$ of those are herbal plant products (Beyene et al. 2016; Sah 2017). India has 
a variety of natural resources, but excessive uses threaten the sources in the wild (Kirtikar and Basu 1994; Abubakar et al. 2018). Tylophora indica (Burm.f.) Merrill. is an important medicinal plant belonging to the family Asclepiadaceae. This perennial climber has a chromosome complement of $2 \mathrm{n}=22$ with $2 \mathrm{~m} . \mathrm{st}+12 \mathrm{M}+6 \mathrm{sm}+2 \mathrm{~m}$ (Samaddar et al. 2012). There are about 90 species spread across Asian, African and Australian regions. It is endangered with a wide spectrum of therapeutic, medicinal properties (Faisal et al. 2007; Anwar et al. 2015). The plant synthesizes a range of alkaloids like tylophorinidine, tylophorine and tylophorinine, and kaempeferol, quercetin, phytosterols and tannin as non alkaloidal compounds demonstrating anti-asthmatic, anti-bacterial, anti-tumor, anti-oxidant and anti-rheumatic properties (Nazar et al. 2020). Kaempeferol and Quercetin are the two most important flavonoids with their potential action against novel COVID-19 as revealed by the Traditional Chinese Medicine Systems Pharmacology (TCMSP) database (Pan et al. 2020).

T. indica has extensively been exploited recently, the lack of cultivation practices, small seed size and poor germination rate complicate the condition and push the plant to the 'endangered' category (Nazar et al. 2020). Traditionally the plants are propagated by seeds and stem cuttings (Anwar et al. 2015); tissue culture has also been used as an alternative propagation method (Soni et al. 2015; Anjum et al. 2014; Chaudhari et al. 2016). Direct and indirect (via callus) are the two most efficient methods used for plant regeneration. Direct organogenesis is practiced more frequently because indirect organogenesis shows genetic changes (Gantait and Kundu 2017; Samarina et al. 2019). Various molecular analyses have been used in detecting variation in several investigated plants but the information is insufficient in $T$. indica (Gantait and Kundu 2017). Flow cytometry (FCM) is a technique used to assess changes in the DNA ploidy of micropropated plants. It is fast, precise and examines a large number of cells/nuclei including the genome in less time (Rewers et al. 2012). Recently, the technique is used in quantifying the content of 2C DNA in different plants (Syeed et al. 2021; Ejaz et al. 2021). Besides, other DNA molecular markers have extensively been used for checking the genetic stability of in vitro regenerated plantlets of which RAPD, ISSR, AFLP and SSR have become a marker of choice (Bose et al. 2016). Recently, genetic fidelity of plants has also been conducted by using a start codon targeted (SCoT) marker. It is an advanced, reliable, efficient, unique and gene-targeted DNA marker and is designed according to a short conserved region flanking the start codon (ATG) in plant genes (Collard and Mackill 2009) exhibiting high reproducibility, unlike other molecular markers where the primer length and annealing temperature is not the sole parameter (Gorji et al. 2011).
The objective of the present study is to establish a reproducible regeneration (direct, indirect and somatic embryo mediated) protocol for propagating Tylophora plants. Flow cytometry and SCoT molecular marker were used in the present study for assessing 2C DNA content and in analyzing the genetic homogeneity / fidelity of regenerated plants.

\section{Materials and methods}

\section{Culture establishment}

Immature, young, healthy leaves and nodes were collected from five years old Tylophora indica (Burm. f.) Merrill. from the herbal garden of Jamia Hamdard, New Delhi, and were used as experimental materials. The excised plant parts (explants) were first washed in running tap water, followed by a soaking in 5\% liquid detergent cetrimide $(\mathrm{v} / \mathrm{v})$ for $10 \mathrm{~min}$; washed thoroughly under running tap water for about $15 \mathrm{~min}$. These explants were surface sterilized with $0.1 \% \mathrm{HgCl}_{2}$ (w/v) for 3-4 min, followed by $70 \%$ ethanol for $20 \mathrm{~s}$ and later flushed with double distilled water 4 to 5 times. Disinfected and surface cleaned explants were cultured on MS (Murashige and Skoog 1962) medium. The above medium was added with $3 \%(\mathrm{w} / \mathrm{v})$ sucrose and $0.8 \%(\mathrm{w} / \mathrm{v})$ agar for solidification; different concentrations of PGRs were added as per in vitro morphogenesis requirement. The $\mathrm{pH}$ of the medium was adjusted to 5.7 with the help of $\mathrm{HCl}$ or $\mathrm{NaOH}$ before autoclaving at $15 \mathrm{lb} \mathrm{inch}^{-2}$ at $121{ }^{\circ} \mathrm{C}$ for $15 \mathrm{~min}$. All the cultures were kept in a culture room maintaining a temperature of $25 \pm 2{ }^{\circ} \mathrm{C}$, the relative humidity of 65-70\% with $12 \mathrm{~h}$ photoperiodic duration equipped with cool-white fluorescent lamps $\left(100 \mu \mathrm{mol} \mathrm{m}{ }^{-2} \mathrm{~s}^{-1}\right.$ Photon flux density, PFD). Subculturing was made at an interval of 3-4 weeks.

\section{Induction of callus and shoot regeneration}

Young leaves and nodal sections were inoculated in $250 \mathrm{ml}$ flask; the callus induction medium was supplemented with different concentrations and combinations of 2, 4-D $(2.25,4.5,6.7,9.0 \mu \mathrm{M})$, NAA $(2.7,5.4,8.0 \mu \mathrm{M})$ and BAP $(2.2,4.4 \mu \mathrm{M})$. The explants started inducing callus within 7-10 days of inoculation, which grew well in mass with every successive culturing. Callus induction frequency and callus weight were recorded after 3 weeks of culture. Profusely green callus obtained from explants was transferred in MS, fortified with various concentrations of BAP and NAA for shoot organogenesis. Mature healthy leaf gave rise to direct shoots when cultured on the same media i.e. BAP and NAA, as used for callus induction. Three to four replicates (one explants/culture tube) were used and each of the 
experiment was repeated thrice. The proliferated shoots were subcultured every 3-4 weeks.

\section{Somatic embryo initiation and proliferation}

The friable callus produced in 2, 4-D added medium transformed into white granular embryogenic callus within 3-4 weeks of culture on which different developmental stages of embryos i.e. globular, heart, torpedo- and cotyledonary were induced on 2, 4-D $(2.25,4.5,6.7 \mu \mathrm{M})$, Kinetin $(4.65,9.30,13.9 \mu \mathrm{M})$ and $\operatorname{BAP}(4.4,8.8,13.2 \mu \mathrm{M})$ amended media. The number of embryos increased with time; periodic and regular subculturing at an interval of 4 weeks was made for more embryo proliferation. Eighteen to twenty test tubes were used per treatment and each of the experiment was replicated thrice.

\section{Embryo maturation, germination and plantlet formation}

The somatic embryos (8-10 per $250 \mathrm{ml}$ flask) were placed in germination media which contained different concentrations of $\operatorname{GA}_{3}(0.7,1.4,2.8 \mu \mathrm{M})$ either alone or in combinations with $\operatorname{BAP}(2.2,4.4,8.8,11.0 \mu \mathrm{M})$. The mature somatic embryos were germinated and developed into plantlets with a distinct shoot and root poles/ends. The embryo germination frequency was calculated after 3-4 weeks of incubation by observing the mean numbers of plants regenerated in each flask.

\section{Histology and scanning electron microscopy (SEM)}

The samples of embryogenic callus were fixed with FAA, which is a mixture of formalin, glacial acetic acid and 70\% ethanol (5:5:90). The tissue was dehydrated in an ethanol series and embedded in paraffin according to the annotation provided by Johansen (1940). Using rotatory microtome (Spencer, USA) equipped with a steel knife, fine sections of about $8 \mu \mathrm{m}$ were made and placed on a glass slide, dewaxed, followed by staining with 5\% hematoxylin and $2 \%$ eosin dye, and mounted in Canada balsam. Prepared slides were photographed after observing under a light microscope (Nikon Optiphot, Japan).

To know the origin, development and surface morphology of somatic embryos, the SEM was performed. The developing embryos and callus tissues were fixed in $2.0 \%$ glutaraldehyde and $2.0 \%$ formaldehyde and maintained in $\mathrm{pH}$ of 6.8 in $0.1 \mathrm{M}$ of phosphate buffer for $24 \mathrm{~h}$ at $4{ }^{\circ} \mathrm{C}$. The tissue was again washed in buffer and later fixed for $2 \mathrm{~h}$ in a similar supported $1.0 \%$ osmium tetroxide, dried out in an ethanol arrangement and ultimately covered with gold palladium. The tests were performed and captured in an LEO-435VP by Zeiss, Oberkochen, Germany using an electron magnifying lens (operational under $20-25 \mathrm{kV}$ ).

\section{Rooting of plantlets}

The micro shoots generated through somatic embryos were small and did not have prominent root ends always, therefore excised microshoots were transferred to the root-inducing medium. Half MS augmented with various auxins were used in both solid and liquid media for root commencement. Different concentrations of NAA $(1.35,2.70,5.4 \mu \mathrm{M})$, IAA $(1.42$, $2.84,5.71 \mu \mathrm{M})$ and IBA $(1.22,2.45,4.9 \mu \mathrm{M})$ were tried independently and in combinations. An equal ratio of soilrite and soil was used as planting substance for acclimatization and higher endurance of recovered plantlets preceding field move. During this period, these regenerated plants were covered with a polythene bag to maintain relative humidity. Three to four replicates were used per treatment and each of the experiment was performed thrice.

\section{Flow cytometry}

T. indica plants grew normally in the field and the tissue culture-derived (directly induced, callus mediated and somatic embryo developed) plants were used for the estimation of $2 \mathrm{C}$ DNA. To check the genetic homogeneity, different in vitro regenerated Tylophora plantlets were selected along with field-grown plants (as control). The optimization of sample processing was made by utilizing the method of Dolezel and Bartos (2005). Five leaf samples from each group (somatic embryogenic, direct organogenesis, indirect organogenesis pathway) were randomly selected along with the mother plant for 2C DNA analysis. Young, immature leaf fragment of 1.0 $\mathrm{cm}^{2}$ size was taken from the field and in vitro grown $T$. indica plants, along with a reference standard Pongamia pinnata with known 2C DNA content of $2.51 \mathrm{pg}$ (Choudhury et al. 2014) were procured on the day of the experiment; finely chopped in $1.0 \mathrm{ml}$ ice-cold Galbraith's buffer $\left(45 \mathrm{mM} \mathrm{MgCl}_{2}, 20 \mathrm{mM}\right.$ MOPS, $30 \mathrm{mM}$ Sodium citrate and $0.1 \%$ Triton-X) using a sharp razor blade. After passing the homogenate through a $42 \mu \mathrm{m}$ nylon mesh, $50 \mu \mathrm{g} \mathrm{ml}^{-1}$ PiRNase (Sigma-Aldrich, USA) was added to the filtrate, provided by a 20-30 min incubation time and finally examined by a CFM BD FACS Calibur (BD Biosciences, San Jose, CA, USA) flow cytometer.

2C DNA content of $T$. indica was estimated by using the following formula:

2C DNA of $T$. indica $=2.51 \mathrm{pg} \frac{\text { Mean of G0/G1 peak of } T \text {. indica }}{\text { Mean of G0/G1 peak of Pongamia pinnata }}$ 
1 pg DNA: 1 pg $=978 \mathrm{Mbp}$ or $0.978 \times 109$ bp (Dolezel 2003).

\section{DNA extraction and SCOT-PCR analysis}

Fresh and young leaves weighing $0.12 \mathrm{~g}$ of $T$. indica were used for total genomic DNA isolation, six randomly selected samples from each group of acclimated plantlets along with the mother plant sample. The extraction of DNA was done using a modified CTAB (Cetyltrimethyl ammonium bromide) based procedure (Doyle and Doyle 1990). Qualitative and quantitative evaluation of total genomic DNA was performed by processing the DNA samples to electrophoresis in $0.8 \%$ agarose gel (Sambrook et al. 1989). DNA samples exhibiting good quality were used for SCoT-PCR reactions.

\section{SCoT-PCR amplifications}

SCoT-PCRs were carried out in $15 \mu \mathrm{l}$ reaction volume, consisting of $100 \mathrm{ng}$ of genomic DNA template, $1 \mathrm{U} / \mu \mathrm{lTaq}$ DNA polymerase (Biootools), $1.5 \mathrm{mM} \mathrm{MgCl} \mathrm{Mg}_{2}$ and $10 \mu \mathrm{M}$ of each dNTPs, $0.2 \mu \mathrm{M}$ of SCoT primer (18 nucleotides long) and sterile deionized water. All the SCoT-PCR reactions were performed using Thermal Cycler (Gene Amp PCR 9700) as follows: an initial denaturation step at $94{ }^{\circ} \mathrm{C}$ for $5 \mathrm{~min}$, followed by 35 cycles of $94{ }^{\circ} \mathrm{C}$ for $30 \mathrm{~s}$, annealing for $30 \mathrm{~s}$ at $50{ }^{\circ} \mathrm{C}$, extension at $72{ }^{\circ} \mathrm{C}$ for $1 \mathrm{~min}$, followed by final extension step at $72^{\circ} \mathrm{C}$ was held for $5 \mathrm{~min}$. After the preliminary screening of 15 primers, six produced stable banding patterns and were selected for genetic stability assessment (Table 3). PCR amplification with the selected SCoT primers was repeated twice. The amplified bands were resolved on $1.5 \%(\mathrm{w} / \mathrm{v})$ agarose electrophoresis made in $1.0 \times \mathrm{TBE}$ buffer and stained with ethidium bromide. $1 \mathrm{~Kb}$ DNA ladder (Gene DireX, Inc.) was used to ascertain the size of amplified DNA fragments. The image of bands was visualized under UV light and photographed using a gel documentation system (Azure Biosystem). The genetic similarity (GS) values between pairs of samples were estimated according to the Jaccard's similarity indices. The similarity matrix was used to construct a phenetic dendrogram using the UPGMA (Unweighted Pair Group Method of Arithmetic Averages, Sneath and Sokal1973) in order to cluster the samples in related groups based on their similarities. The analysis for the UPGMA cluster was performed using NTSYS-pc software (version 2.02, Rohlf 2005).

\section{Statistical analysis}

All investigations under the current study were set up in a completely randomized design. The experiments were conducted in triplicates unless specified so. Data were analyzed by analysis of variance using SPSS software SPSS v. 16 (SPSS Inc., Chicago, USA). The means were separated using (DMRT) Duncan's multiple range testing method and significance were determined at $\mathrm{p} \leq 0.05$. Deviation to the mean was calculated as Standard Error (SE).

\section{Results}

\section{Callus induction and shoot regeneration/ organogenesis}

The healthy, greenish and friable callus was induced within 3 weeks of culture from leaf and node explants on MS, fortified with different concentrations of 2, 4-D, BAP and NAA. The callus induction frequency and the callus weight from different explants in response to various PGRs were examined and the responses are presented in Supp. Fig. 1a, b. Out of diverse treatments, the highest callus induction frequency $(87.75 \%)$ was observed in leaf on $6.7 \mu \mathrm{M} 2$, 4-D added medium, and for nodal explant, the maximum callus induction frequency was $70.91 \%$ (Supp. Table 1). The lowest callus induction frequency was noted in $6.7 \mu \mathrm{M} 2,4-\mathrm{D}+4.4 \mu \mathrm{M}$ BAP augmented medium from the leaf $(24.11 \%)$ and node (14.38\%). The same concentration of PGR elicited a good increment of callus mass as observed during callus induction time. Hence, the combination of auxin and cytokinin was noted to be less responsive in producing vigorous callus compared to auxin alone, which triggered a fairly good amount of callus in $T$. indica. The leaves were observed to be more responsive as compared to the nodal explant as it produced intense callus which started to appear within a couple of weeks of culture (Supp. Fig. 1c, d). The callus quality was noted good, appeared initially as friable, later became compact and yellowish-green, grew vigorously on subculturing in MS, supplemented with same levels of PGRs. Profusely obtained leaf-callus was cultured in MS enriched with various levels of BAP and NAA for shoot formation and subcultured successively.

\section{Somatic embryo initiation and proliferation}

Leaf and nodal parts on MS medium responded differently i.e. the mature leaf responded to direct embryogenesis (Fig. 1a) and shoot formation (Fig. 1b) but not the nodal explants, when cultured with different BAP added concentrations. Within 10-12 days of culture, the small bud was formed and flourished well in BAP optimized medium 

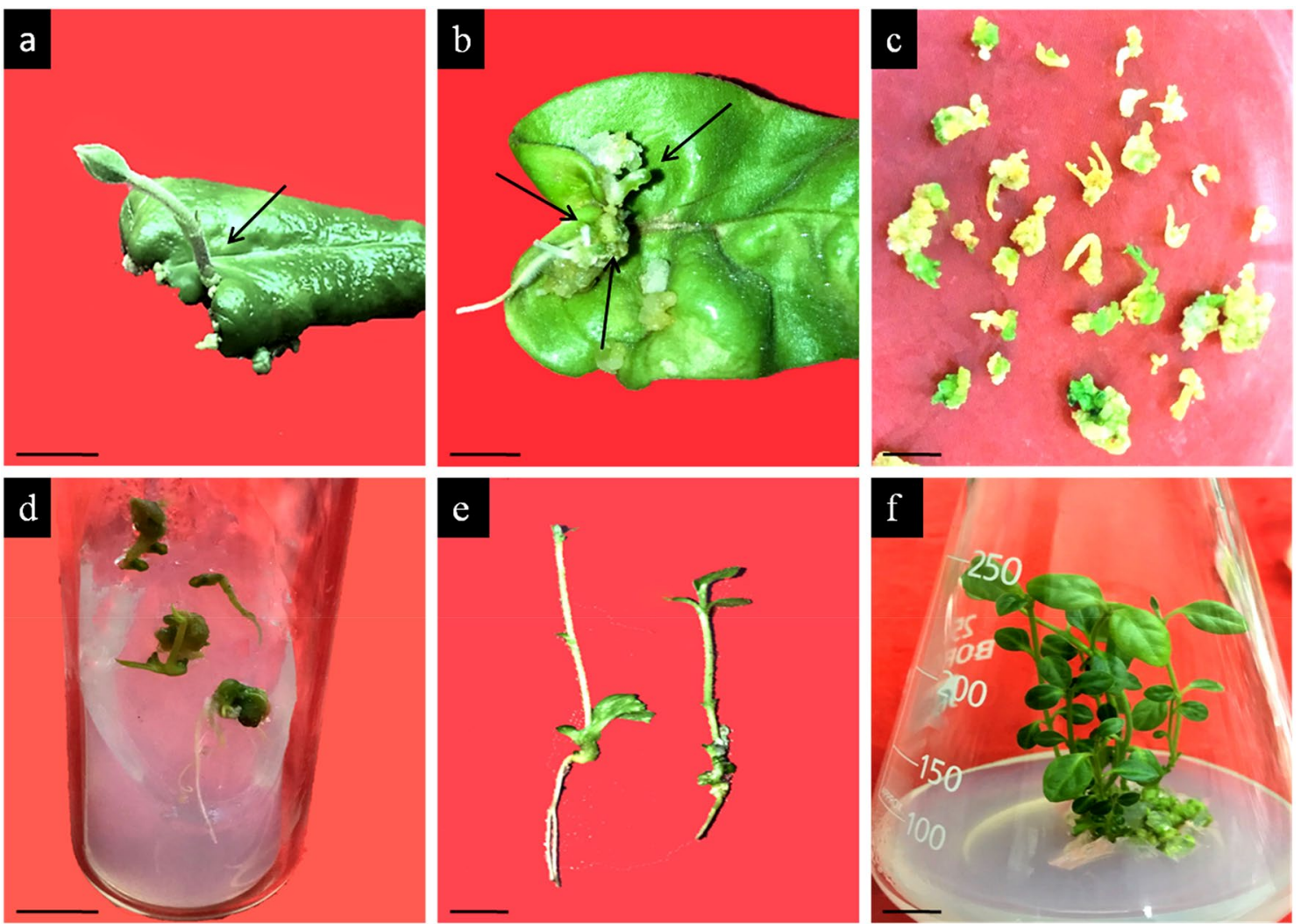

Fig. 1 a Direct organogenesis from mature leaf (Arrow head). b Direct embryogenesis from mature leaf in MS medium supplemented with $9.3 \mu \mathrm{M}$ Kinetin $+4.5 \mu \mathrm{M}$ 2,4-D. c Mature embryos at different stages of somatic embryogenesis. d Germinated embryos obtained

(data are not shown), and on regular subculturing it developed into a shoot. Beside direct formation of shoots, bipolar 'embryo-like' structures were observed directly from the leaf without any callus formation on $9.3 \mu \mathrm{M}$ Kinetin and $4.5 \mu \mathrm{M}$ in $8.8 \mu \mathrm{M} \mathrm{BAP}+1.4 \mu \mathrm{M} \mathrm{GA}_{3}$ added MS medium e fully germinated embryos. f Successful shoot induction after 6 weeks of culture (Bars: $\mathbf{a}, \mathbf{b}, \mathbf{c}, \mathbf{e}, \mathbf{f}, 0.5 \mathrm{~cm} ; \mathbf{d}, 1 \mathrm{~cm})$

2,4-D amended MS medium with a moderate frequency of $40.27 \%$ embryogenesis. Leaf induced callus showed somatic embryogenesis $(65.50 \%)$ with variable numbers of embryos, maximum i.e. 6.3 being in $9.3 \mu \mathrm{M}$ Kinetin added medium,
Table 1 Direct and indirect somatic embryogenesis from leaf explants in different concentrations and combinations of PGRs in MS media of $T$. indica

\begin{tabular}{|c|c|c|c|c|c|}
\hline \multicolumn{3}{|c|}{ PGRs $(\mu \mathrm{M})$} & \multicolumn{2}{|c|}{ Embryogenesis \% } & \multirow{2}{*}{$\begin{array}{l}\text { Mean no. } \\
\text { of somatic } \\
\text { embryos/ } \\
\text { culture }\end{array}$} \\
\hline Kinetin & BAP & $2,4-\mathrm{D}$ & Direct & Indirect & \\
\hline 4.65 & & & $27.73 \pm 1.18 \mathrm{c}$ & $59.32 \pm 1.00 \mathrm{~b}$ & $5.7 \pm 0.11 b$ \\
\hline 9.30 & & & $34.41 \pm 1.62 b$ & $65.50 \pm 1.35 \mathrm{a}$ & $6.3 \pm 0.32 \mathrm{a}$ \\
\hline \multirow[t]{4}{*}{13.9} & & & $28.27 \pm 1.04 \mathrm{c}$ & $51.79 \pm 1.83 \mathrm{c}$ & $4.4 \pm 0.05 c$ \\
\hline & 4.4 & & $19.95 \pm 1.05 \mathrm{~d}$ & $43.17 \pm 0.78 \mathrm{de}$ & $3.8 \pm 0.15 \mathrm{~d}$ \\
\hline & 8.8 & & $17.51 \pm 1.14 \mathrm{~d}$ & $46.48 \pm 0.68 d$ & $4.1 \pm 0.20 \mathrm{~cd}$ \\
\hline & 13.2 & & $13.42 \pm 1.13 \mathrm{e}$ & $41.50 \pm 1.27 \mathrm{e}$ & $2.3 \pm 0.15 f$ \\
\hline 9.30 & & 2.25 & $28.74 \pm 0.82 \mathrm{c}$ & $45.42 \pm 0.47 d$ & $3.7 \pm 0.05 \mathrm{~d}$ \\
\hline 9.30 & & 4.5 & $40.27 \pm 1.02 \mathrm{a}$ & $49.83 \pm 0.68 c$ & $4.3 \pm 0.10 \mathrm{c}$ \\
\hline 9.30 & & 6.7 & $34.62 \pm 0.67 b$ & $43.71 \pm 0.99 \mathrm{de}$ & $3.2 \pm 0.05 \mathrm{be}$ \\
\hline
\end{tabular}

The data was scored after 3 weeks of inoculation. Values are means \pm standard error $(n=18)$. Means within columns followed by the different letters are significantly different at $\mathrm{p} \leq 0.05$ using Duncan's multiple range test (DMRT) 
followed by $4.65 \mu \mathrm{M}$ Kinetin where an average of 5.7 somatic embryos/callus mass were noted (Table 1; Fig. 1c).

Node callus was noted to be less potent in evoking embryogenesis as no or poor numbers of embryos were formed, therefore was discontinued for future embryogenic or morphogenic studies. The embryos obtained from these two sources (direct and indirect) were morphologically similar and easily detachable from the mother leaf and callus tissue without any damage, which were processed for embryo germination.

\section{Embryo maturation, germination and plantlet formation}

The mature green embryos were placed in MS augmented with various $\mathrm{GA}_{3}$ concentrations $(0.7,1.4,2.8 \mu \mathrm{M})$ alone and in combination with BAP $(2.2,4.4,8.8,11.0 \mu \mathrm{M})$. Among the different concentrations tested, $1.4 \mu \mathrm{M} \mathrm{GA}_{3}$ happened to produce $62.21 \%$ somatic embryo germination with a 12.37 mean number of shoots/flask (Supp. Table 2). Somatic embryo germination frequency was improved (72.38\%) further on BAP $(8.8 \mu \mathrm{M})$ added $\mathrm{GA}_{3}(1.4 \mu \mathrm{M})$ medium (Fig. 1d). Around 75-80 shoots were produced from a leaf-derived $500 \mathrm{mg}$ of callus within 4-5 months times which were rooted before transplantation.

\section{Histological and scanning electron microscopy study}

A comprehensive histological study was undertaken to get a better understanding of the cellular changes taking place when organogenesis occurred via callus. Histological study revealed the development of embryos (Fig. 2a, b) and the cellular origin of plant regeneration. The embryos and pro embryos with no distinct suspensor were seen in non-synchronized fashion and without any association with mother tissue leading to the formation of shoot and root meristems. The organogenic callus investigated through SEM also supported the genesis and development of somatic embryo
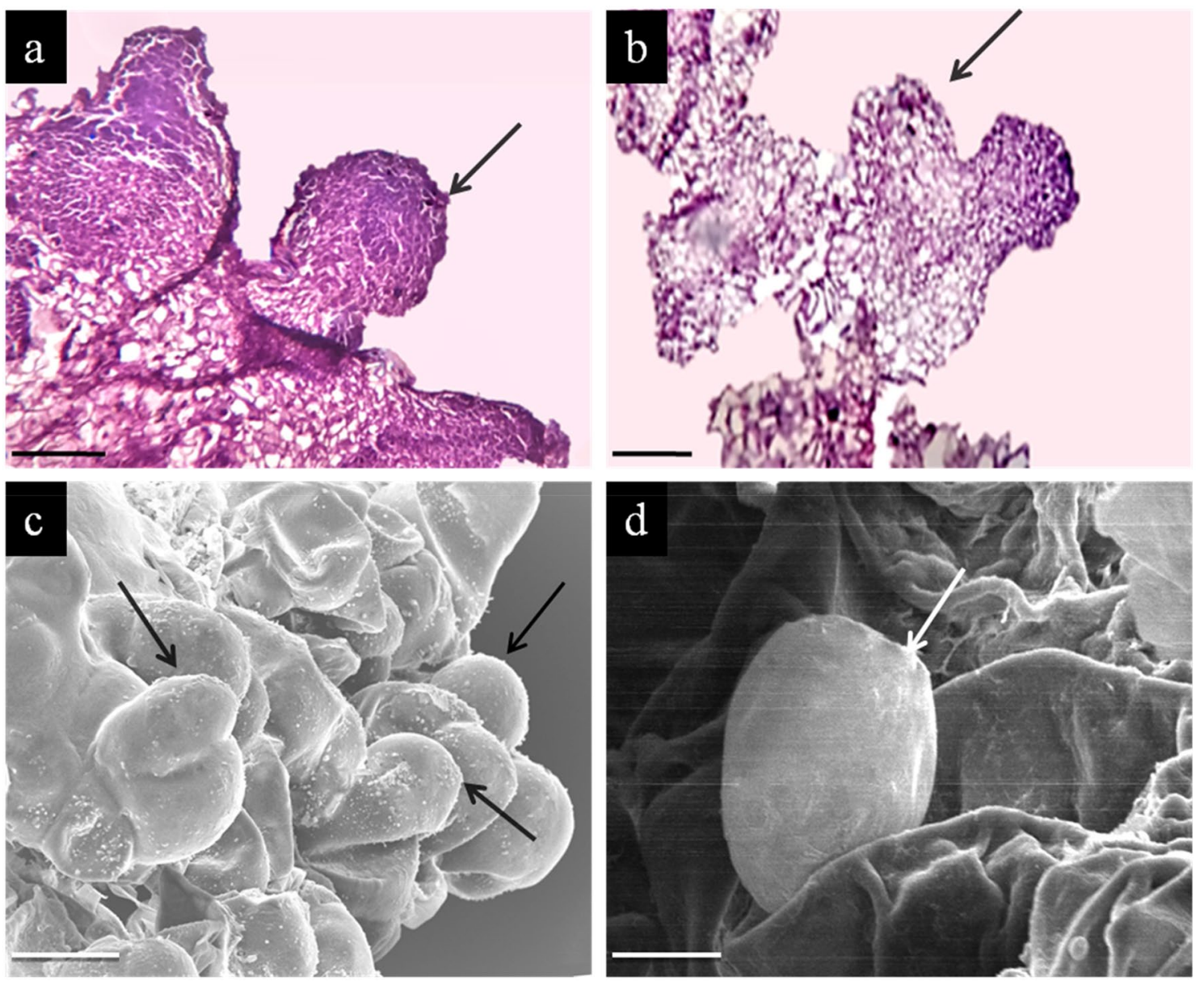

Fig. 2 Histological study of embryo at different stages. a Globular embryo. b Heart shaped. SEM investigation confirming SE. c, d Heart shaped embryos and Globular embryo developed on the surface of embryogenic callus (Arrow heads) (Bars: a, b $1 \mathrm{~mm} ; \mathbf{c} 10 \mu \mathrm{m} ; \mathbf{d} 100 \mu \mathrm{m}$ ) 
(Fig. 2c, d) confirming other developmental features on the callus surface before taking the shape of shoot and root meristem in an embryo. Surface morphology of different developmental stages of embryos i.e. globular, heart, torpedo, cotyledonary embryo could easily be visualized through histology and SEM preparations.

\section{Induction of roots and transfer of plants to outdoor conditions}

The regenerated shoots obtained from different pathways (Supp. Fig. 2a) were placed in half MS both solid and liquid medium (Supp. Fig 2b-d) augmented with IAA, IBA and NAA at different concentrations for root regeneration. Both the medium induced roots and the liquid medium responded well in promoting more number of roots/shoot.
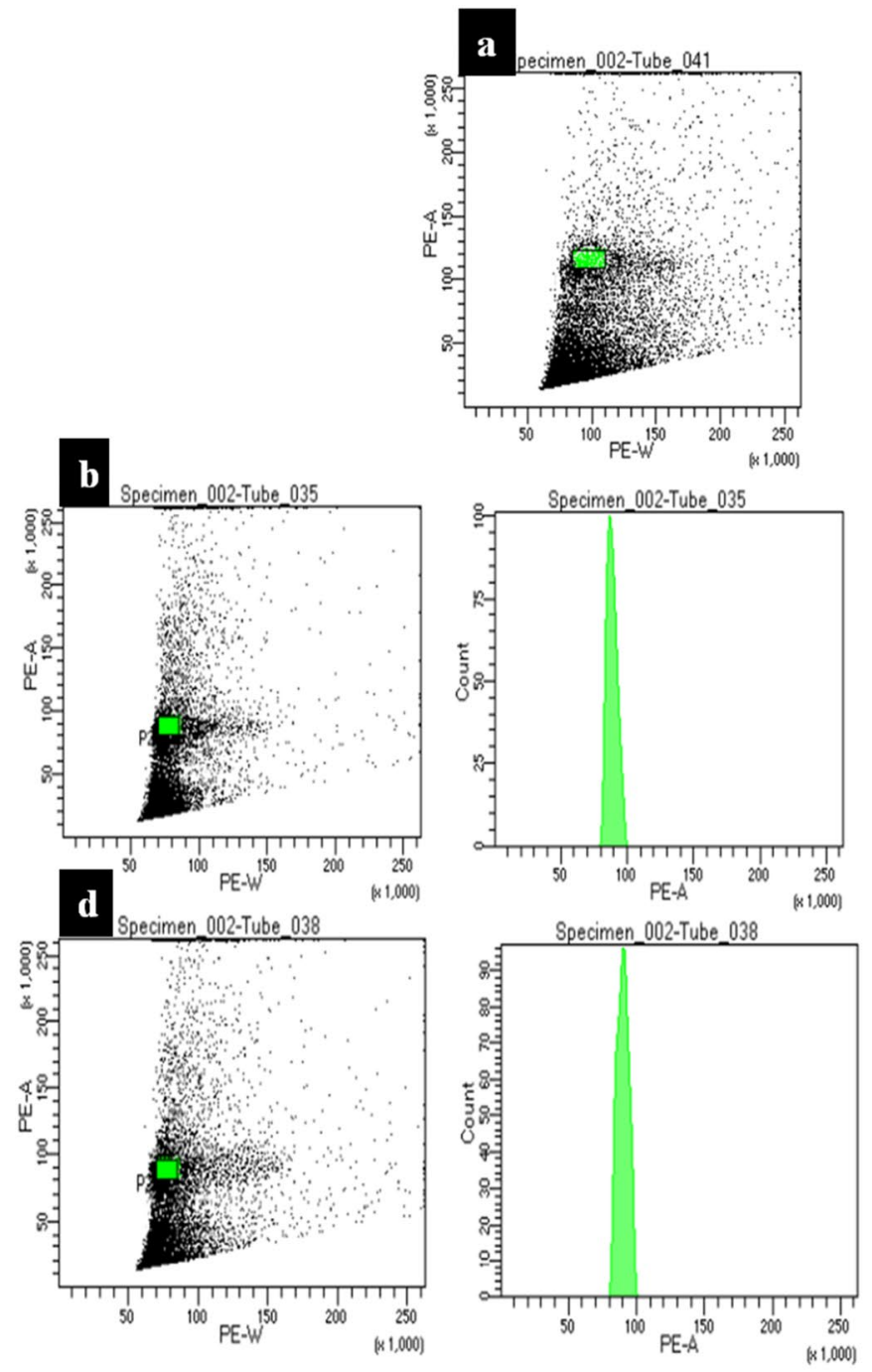

Fig. 3 Flow cytometric analysis showing dot plots and histograms of relative nuclear DNA content isolated from leaves of a Pongamia pinnata (standard), b Indirect, c Direct induced, d Somatic embryo
IAA and IBA induced roots but the best response was noted in $2.45 \mu \mathrm{M}$ IBA added conditions with root induction efficiency of $88.17 \%$ in solid and $67.11 \%$ in liquid medium (Supp. Table 3). A maximum of $8.90 \pm 0.04$ roots per microshoot in liquid and $6.82 \pm 0.08$ roots per shoot were recorded in solid medium after 5 weeks of incubation (Table 3). Welldeveloped rooted plants were hardened inside the culture room in soilrite and soil (1:1) for four weeks, followed by transfer to pots (Supp. Fig 2e), containing soil, where the plants were grown under natural light with a $90 \%$ survival rate.

\section{C nuclear DNA content}

In vitro grown culture particularly the callus is affected by stress, PGRs and other chemicals in medium, which induce
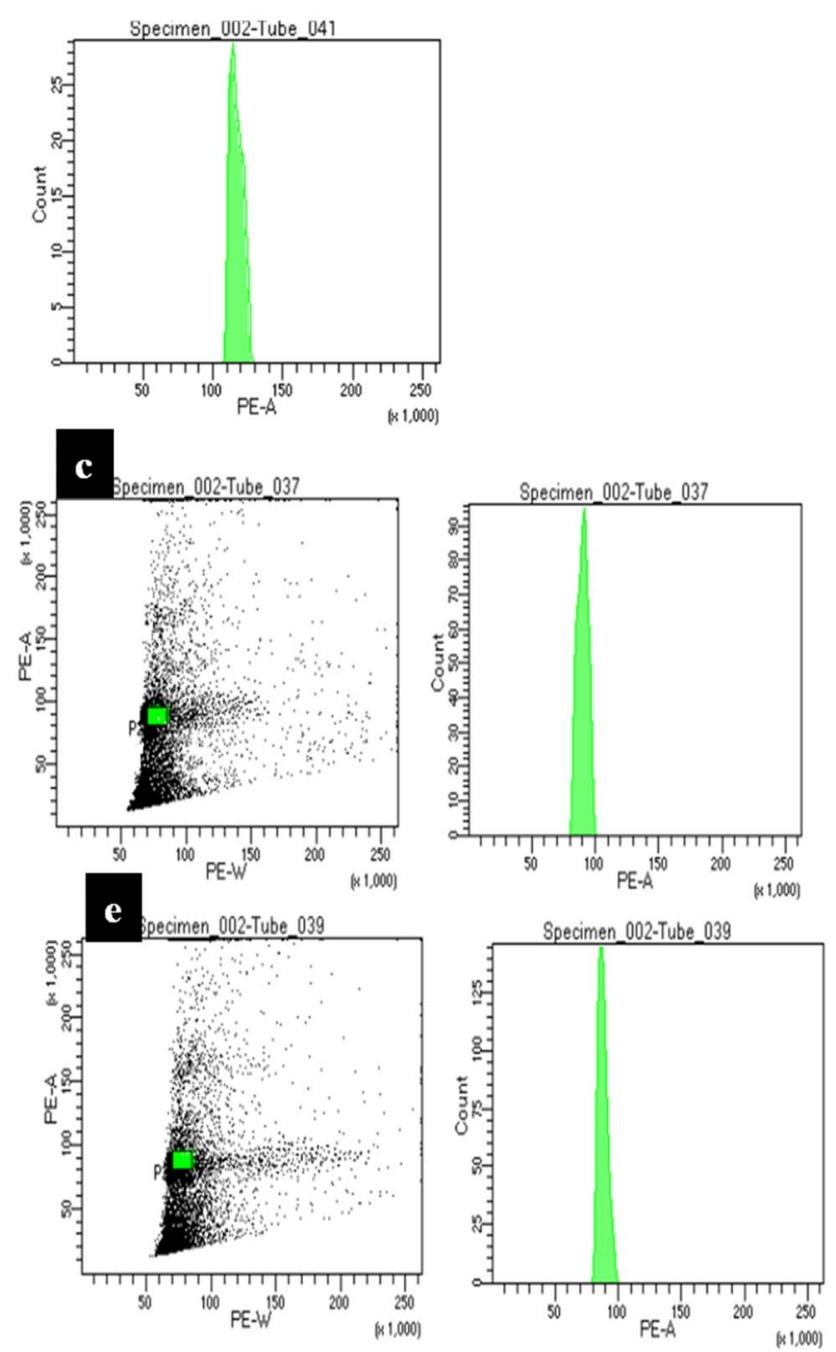

regenerated, e Ex-vitro procured $T$. indica. Left panels show dot plot of PE-W/ PE-A in which singlet G0/G1 population is gated and observed within the count versus PE-A histogram plot 
Table 2 2C DNA content of $T$ indica regenerants obtained via direct, indirect and embryogenesis pathways

\begin{tabular}{llll}
\hline Plant source & 2C DNA content (pg) & Genome size (Mbp) & $\begin{array}{l}\text { Coefficient of } \\
\text { variation (\%) }\end{array}$ \\
\hline In vivo plant (donor plant) & $1.928 \pm 0.07 \mathrm{a}$ & $1885.58 \mathrm{a}$ & 4.3 \\
Direct regenerated plantlets & $1.926 \pm 0.03 \mathrm{a}$ & $1883.62 \mathrm{a}$ & 4.4 \\
Callus mediated plantlets & $1.940 \pm 0.01 \mathrm{a}$ & $1854.28 \mathrm{a}$ & 4.5 \\
Plantlets regenerated via Embryo & $1.896 \pm 0.07 \mathrm{a}$ & $1897.32 \mathrm{a}$ & 4.2 \\
\hline
\end{tabular}

Data is represented as mean SE $(n=3)$

Mean values in each column followed by different letters are significantly different at $p \leq 0.05$ using Duncan's multiple range test DMRT. Mbp mega base pair, $p g$ pico gram

${ }^{a} 1$ pg DNA: 1 pg =978 Mbp or $0.978 \times 109$ bp (Dolezel 2003)

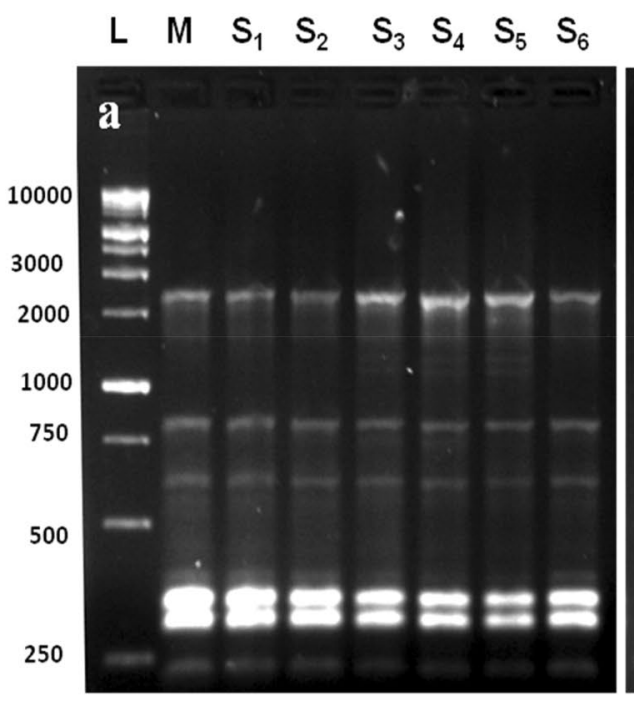

\section{$\begin{array}{llllllllll}L & M & S_{7} & S_{8} & S_{9} & S_{10} & S_{11} & S_{12}\end{array}$}

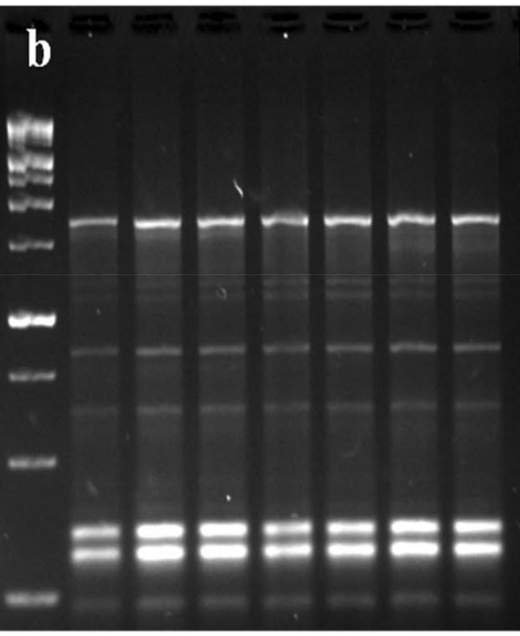

$\begin{array}{lllllll}M & S_{13} & S_{14} & S_{15} & S_{16} & S_{17} & S_{18}\end{array}$

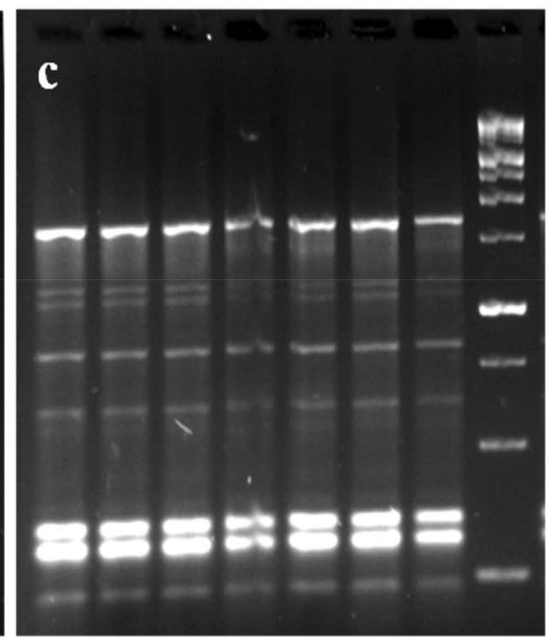

Fig. 4 SCoT profiles showing monomorphic bands in $T$. indica amplified with SCoT-4 for in vitro derived plants and mother plant. Lane $(\mathrm{L})$ : ladder $(1 \mathrm{~kb})$; Lane $(\mathrm{M})$ : mother plant; various micropro- pagated plant: Lane A $S_{1}-S_{6}$ regenerants generated via callus, B $S_{7}-$ $\mathrm{S}_{12}$ directly regenerated plantlets and $\mathbf{C ~ S}_{13}-\mathrm{S}_{18}$ embryo regenerated plantlets
Table 3 List of SCoT primer sequences with the number, annealing temperature of scorable amplified fragments and length of DNA bands produced in Tylophora indica mother plant and in vitro obtained plants

\begin{tabular}{|c|c|c|c|c|c|c|c|c|}
\hline \multirow[t]{2}{*}{ Sr No } & \multirow[t]{2}{*}{ Primer code } & \multirow[t]{2}{*}{ Sequences $\left(5^{\prime}-3^{\prime}\right)$} & \multirow[t]{2}{*}{$\% \mathrm{G} / \mathrm{C}$} & \multirow[t]{2}{*}{$\operatorname{Tm}\left({ }^{\circ} \mathrm{C}\right)$} & \multirow{2}{*}{\multicolumn{3}{|c|}{$\begin{array}{l}\begin{array}{l}\text { Number of } \\
\text { scorable } \\
\text { bands }\end{array} \\
\left(\mathrm{S}_{1}-\mathrm{S}_{6}\right)\left(\mathrm{S}_{7-}\right. \\
\left.\mathrm{S}_{12}\right)\left(\mathrm{S}_{13}-\mathrm{S}_{18}\right)\end{array}$}} & \multirow[t]{2}{*}{$\begin{array}{l}\text { Range } \\
\text { of DNA } \\
\text { bands(bp) }\end{array}$} \\
\hline & & & & & & & & \\
\hline 1 & SCoT3 & CAACAATGGCTACCACCG & 56 & 48 & 15 & 15 & 15 & $300-1400$ \\
\hline 2 & SCoT4 & CAACAATGGCTACCACCT & 50 & 48 & 8 & 8 & 8 & $250-1200$ \\
\hline 3 & SCoT7 & CAACAATGGCTACCACGG & 56 & 50 & 4 & 4 & 2 & $300-1800$ \\
\hline 4 & SCoT9 & CAACAATGGCTACCAGCA & 50 & 48 & 8 & 8 & 8 & $200-2800$ \\
\hline 5 & SCoT12 & ACGACATGGCGACCAACG & 61 & 50 & 5 & 6 & 6 & $400-1200$ \\
\hline 6 & SCoT26 & ACCATGGCTACCACCGTC & 61 & 50 & 4 & 4 & 4 & $350-1400$ \\
\hline
\end{tabular}

$\mathrm{S}_{1}-\mathrm{S}_{6}, \mathrm{~S}_{7}-\mathrm{S}_{12}, \mathrm{~S}_{13}-\mathrm{S}_{18}$ depicts direct, indirect and embryo regenerated plantlet samples. The SCoT marker generated data shows scorable bands with band size ranging from 200 to $2800 \mathrm{bp}$. Highly reproducible monomorphic bands confirm genetic homogeneity of in vitro obtained plants, similar to T.indica mother (donor) plant 
genetic instability in cultivated tissues. In order to determine the genetic status, the 2C DNA content of the regenerated plant was measured in $T$. indica. Flow cytometry study (Fig. 3a-e) shows that the 2C DNA content of in vitro raised i.e. direct, indirect organogenesis and somatic embryogenesis and field-grown plant of $T$. indica are the same as the nuclear 2C DNA values are 1.926, 1.940, 1.896, $1.928 \mathrm{pg}$ respectively (Table 2). The similarity in genome size of both the two groups of plants (in vitro and field grown) was affirmed by our observation. We therefore conclude that the genetic homogeneity/similarity was maintained in cultured tissues, the regenerants were therefore true to type i.e. the genetic morphology of in vitro raised plant is identical to the field-grown /mother plant.

\section{SCoT marker analysis}

In tissue culture obtained plants, it is necessary to ensure genetic stability especially when the culture is produced through callogenesis or embryogenesis. In addition to genome size analysis through flow cytometry, the present study validates the genetic fidelity of micropropagated $\left(\mathrm{S}_{1}-\mathrm{S}_{18}\right)$ plants with mother plant $(\mathrm{M})$ using SCoT marker. Genomic DNA extraction and quantification of $T$. indica were successfully achieved on $0.8 \%$ agarose gel (Supp. Fig. 3). For analysis of genetic homogeneity, six primers were selected out of 15 screened SCoT primers with an average 8 bands/primer (Fig. $4 \mathrm{a}-\mathrm{c}$ ). $\mathrm{SCoT}_{3}$ produced maximum 15 bands whereas $\mathrm{SCoT}_{7}$ produced the least 3 bands (Table 3). UPGMA dendrogram based on Jaccard's similarity indices obtained from SCoT markers showing $94 \%$ similarity between mother plant $(\mathrm{M})$ and regenerated plants $\left(\mathrm{S}_{1}-\mathrm{S}_{18}\right)$ of $T$. indica (Supp. Fig. 4).

\section{Discussion}

The present study describes the role of various PGRs on callus induction, direct regeneration, and embryogenesis in $T$. indica. Callus induction ability from the two explant types (leaf and node) was tested and it was noted that the 2,4-D and Kinetin triggered the initiation, multiplication of cells and stimulated somatic embryogenesis in Tylophora. The callus was induced from both the explants, proliferated fast on 2,4-D added medium. Similarly, the impact of 2,4-D in inducing callus was investigated in different other plant species (You et al. 2011; Malik et al. 2020b). In T. indica, a very similar report or better response of 2,4-D (in comparison to TDZ) in producing callus was noted (Chandrashekhar et al. 2006), which is different from Sahai et al. (2010) observation where BAP's potency in inducing callus was reported. Here, for callus-mediated de novo shoot production, the MS added with BAP and NAA was observed to be efficient, corroborating earlier report (Teixeira da Silva and Jha 2016). This study revealed that out of two explants (leaf and nodal stem) tested, the leaf continuously induced callus on which embryos were formed at variable numbers. The leaves were also programmed to induce the embryo directly (without any callus); the nodal stem on the other did not produce any embryo or shoot directly. Although the reason for differential behavior of explants is not known clearly, the differential physiological gradients like endogenous PGR level, photosynthetic reserves present in different explants perhaps responsible for varied morphogenetic responses (Wernicke and Milkovits 1986; Mujib 2005). Delporte et al. (2014) reported that a variety of PGRs and their combinations influenced differential cells' activity in exhibiting varied explant behavior; and thus need a specific level of PGR/s at different stages of morphogenesis.

Somatic embryogenesis is a sequential process where somatic cells acquire cellular totipotency under an appropriate culture environment and induce embryogenic cells and embryos (Feher 2015, Gulzar et al. 2019). The plant produced via callogenesis shows the stages of callus formation, acquisition of embryogenic cells, embryo formation, maturation and plantlet regeneration (Von Arnold et al. 2002). These steps are governed by the restructuring of the cellular state through various physiological, biochemical and molecular processes (Sharmin et al. 2014). In T. indica, callus was obtained on 2,4-D supplemented MS medium on which embryo induction was noted, but the continuous presence impedes the development, very similar to Tahir et al. (2011) observation where 2,4-D in medium prevented embryo progression in Saccharum officinarum. Here, Kinetin alone and in combination with 2,4-D was noted to be more efficient for embryo development and advancement. Several other researchers demonstrated auxins specifically 2,4-D's efficacy (as most significant and strong PGR) in initiating somatic embryos in different plant species (Zhang et al. 2007; Gulzar et al. 2019). Since Daucus carrota, the incidence of somatic embryogenesis has been reported widely and histological and SEM evidence has been presented in many plant species (Couillerot et al. 2012; Mujib et al. 2013). The induced somatic embryos of Tylophora were later germinated and produced plants in BAP and $\mathrm{GA}_{3}$ added medium.

Beside embryogenesis, the shoots were induced directly on explants and via callus, which needed to be rooted before transplantation. In this study, various PGR treatments were used in solid and liquid medium for rooting and all the treatments induced roots at variable numbers. IBA supplemented half MS liquid medium produced more numbers of roots but the roots were stout and thick in solid medium. The positive influence of auxins especially IBA in solid/liquid media in inducing roots has been reported in a variety of plant genera (Aslam et al. 2013; Dipti et al. 2014; Mujib et al. 2017). In Clerodendrum phlomidis, Kher et al. (2016) 
however, reported good numbers of roots in NAA added half MS medium.

The culture of callus on PGR added media for an extended period of time may cause stress to tissues which promote alterations in DNA and causes genetic instability (Pal et al. 2007; Chakraborty et al. 2013). These variations are demonstrated to be heritable and noted to be undesirable in somatic clones; such variations need to be detected at an early stage of plant development (Yang et al. 2011). There are several traditional and modern techniques to identify these genetic changes (Das et al. 2013). Here in T. indica, the plants were developed directly and indirectly from explants. The 2C DNA content of regenerated plant was evaluated; the histogram peaks of direct, callus mediated and embryo generated plants were similar to field-grown $T$. indica $2 \mathrm{C}$ DNA peak. Thus, the ploidy level and the genetic homogeneity were maintained which is in line with Niazian et al. (2017) observation, showing the genetic stability of regenerated plants in Carum copticum. Recently, similar genome size stability was reported in micropropagated plants of Gladiolus (Mujib et al. 2017), Rauvolfia serpentina (Zafar et al. 2019), Allium sativum (Malik et al. 2020a) and species of Zepheranthes (Syeed et al. 2021). The alteration of genetic complement was however, reported in other investigated plants like Elaeis guineensis and Cucumis melo of tissue culture origin (Giorgetti et al. 2011; Raji and Farajpore 2020). The genetic homogeneity has also been validated by other molecular marker techniques and was reported in several plant species demonstrating monomorphic band patterns (Rathore et al. 2014; Rajput and Agrawal 2020). Sharma et al. (2014) reported clonal fidelity using ISSR molecular marker in Tylophora indica. The implementation of SCoT marker for investigating true to type nature of micropropagated plants was conducted and monomorphism confirming genetic stability was noted in Citrus x meyeri (Najwa et al. 2021). In this study, a high degree of similarity of tissue cultured and mother Tylophora plant was established through SCoT marker. Dendrogram obtained from UPGMA revealed 94\% similarity between parent and regenerated plants. Similar to our findings SCoT marker revealed a low degree of genetic variability in several other studied plant materials like Dendrobium thyrsiflorum, Plumbago zeylanica and Atropa acuminata (Bhattacharyya et al. 2015; Sharma and Agrawal 2018; Rajput and Agrawal 2020). Using SCoT marker Bhattacharyya et al. (2017) reported dissimilarity between the mother plant and the regenerants of Rumex nepalensis.

\section{Conclusion}

The present study showed no alteration in plant genetic makeup, which affirms clonal homogeneity among the regenerated plantlets obtained from different ways (directly, callus and somatic embryo mediated). Tylophora, being a potential source of active phytochemicals can be propagated using the above method for further in vitro enhancement of important secondary metabolites without exploiting the wild. Flow cytometry and SCoT molecular marker can be used as a robust technique for future plant breeding programs for cultivating true-to-type plants of high economic value.

Supplementary Information The online version contains supplementary material available at https://doi.org/10.1007/s11240-022-02254-z.

Acknowledgements We are highly grateful to BD-JH FACS Academy and also to Application scientist Dr. Shwetanjali for authorizing the flow cytometry facility. We are thankful to the Department of Botany, Jamia Hamdard for providing us the lab facilities.

Funding This study was funded by Hamdard National Foundation

Data availability The authors certify that all the data are available within this manuscript.

\section{Declarations}

Conflict of interest The authors declare no conflict of interest in this article.

Ethical approval This work did not involve any study related to animals and human volunteer.

\section{References}

Abubakar BM, Salleh FM, Shamsir OMS, Wagiran A (2018) Assessing product adulteration of Eurycoma longifolia (Tongkat Ali) herbal medicinal product using DNA barcoding and HPLC analysis. Pharmabiol 56(1):368-377

Anjum A, Narula A, Khan A, Kamaluddin, (2014) Establishment of an in vitro micropropagation protocol for a medicinal herb Tylophora indica. J Cell Tissue Res 14:4309-4314

Anwar S, Anamica U, Shiwali S, Taiba S (2015) Tylophora indica (Burm. f.) Merrill: medicinal uses, propagation, and replenishment. In: Anwar S, Sharma S, Siddiqui SA (eds) Biotechnological strategies for the conservation of medicinal and ornamental climbers. Springer International Publishing, Switzerland, pp 239-258

Aslam J, Mujib A, Sharma MP (2013) In vitro micropropagation of Dracaena sanderiana Sander ex Mast: an important indoor ornamental plant. Saudi J Biol Sci 20:63-68

Beyene B, Beyene B, Deribe H (2016) Review on application and management of medicinal plants for the livelihood of the local community. J Res Dev Mange 22:33-39

Bhattacharyya P, Kumaria S, Job N, Tandon P (2015) Phyto-molecular profiling and assessment of antioxidant activity within 
micropropagated plants of Dendrobium thyrsiflorum: a threatened medicinal orchid. Plant Cell Tiss Organ Cult 122:535-550

Bhattacharyya P, Kumaria S, Bose B, Paul P, Tandon P (2017) Evaluation of genetic stability and analysis of phytomedicinal potential in micropropagated plants of Rumex nepalensis-A medicinally important source of pharmaceutical biomolecules. J Appl Res Med Aromat Plants 6:80-91

Bose B, Kumaria S, Choudhury H, Tandon P (2016) Assessment of genetic homogeneity and analysis of phytomedicinal potential in micropropagated plants of Nardostachys jatamansi, a critically endangered, medicinal plant of alpine Himalayas. Plant Cell Tiss Organ Cult 124:331-349

Chakraborty N, Banerjee D, Ghosh M, Pradhan P, Gupta NS, Acharya $\mathrm{K}$, Banerjee M (2013) Influence of plant growth regulators on callus mediated regeneration and secondary metabolites synthesis in Withania somnifera (L.) Dunal. Physiol Mol Biol Plants 19(1):117-125

Chandrasekhar T, Hussain TM, Ramagopal G, Rao JS (2006) Somatic embryogenesis of Tylophora indica (Burm. f.) Merrill., an important medicinal plant. Int J App Sci Eng 4:33-40

Chaudhari VK, Singh S, Singh AK (2016) Recent progress in understanding of medicinal plants biotechnology. Int J Curr Trends Pharm Res 4(2):109-114

Choudhury RR, Basak S, Ramesh AM, Rangan L (2014) Nuclear DNA content of Pongamia pinnata $\mathrm{L}$. and genome size stability of in vitro-regenerated plantlets. Protoplasma 251(3):703-709

Collard BC, Mackill DJ (2009) Start codon targeted (SCoT) polymorphism: a simple, novel DNA marker technique for generating gene-targeted markers in plants. Plant Mol Biol Rep 27:86-93

Couillerot JP, Windels D, Vazquez F, Michalski JC, Hilbert JL, Blervacq AS (2012) Pretreatments, conditioned medium and co-culture increase the incidence of somatic embryogenesis of different Cichorium species. Plant Signal Behav 7(1):1-11

Das A, Kesari V, Rangan L (2013) Micropropagation and cytogenetic assessment of Zingiber species of Northeast India. Biotechnol 3:471-479

Delporte F, Pretova A, Jardin P, Watillon B (2014) Morpho-histology and genotype dependence of in vitro morphogenesis in mature embryo cultures of wheat. Protoplasma 251:1455-1470

Dipti T, Fatima S, Mujib A (2014) Morphological anomalies in somatic embryo structure in Catharanthus roseus: improving embryo germination by amending plant growth regulators, activated charcoal and sucrose level. British Biotechnol J 4(1):10-20

Dolezel J (2003) Nuclear DNA content and genome size of trout and human. Cytom Part A 51:127-128

Dolezel J, Bartos J (2005) Plant DNA flow cytometry and estimation of nuclear genome size. Ann Bot 95(1):99-110

Doyle JJ, Doyle JL (1990) Isolation of plant DNA from fresh tissue. Focus 12:13-15

Ejaz B, Mujib A, Mamgain J, Malik MQ, Syeed R, Gulzar B, Bansal Y (2021) Comprehensive in vitro regeneration study with SCoT marker assisted clonal stability assessment and flow cytometric genome size analysis of Carthamus tinctorius L.: an important medicinal plant. Plant Cell Tiss Organ Cult. https://doi.org/10. 1007/s11240-021-02197-x

Faisal M, Ahmad N, Anis M (2007) An efficient micropropagation system for Tylophora indica: an endangered, medicinally important plant. Plant Biotechnology Reports 1(3):155-161

Feher A (2015) Somatic embryogenesis-stress-induced remodeling of plant cell fate. Biochim Biophys Acta 1849(4):385-402

Gantait S, Kundu S (2017) Neoteric trends in tissue culture-mediated biotechnology of Indian ipecac [Tylophora indica (Burm. F.) Merrill]. 3 Biotech 7(3):1-15

Giorgetti L, Ruffini-Castiglione M, Turrini A, Martini G, NutiRonchi V, Geri C (2011) Cytogenetic and histological approach for early detection of "mantled" somaclonal variants of oil palm regenerated by somatic embryogenesis: first results on the characterization of regeneration system. Caryologia 64:223-234

Gorji AM, Poczai P, Polgar Z, Taller J (2011) Efficiency of arbitrarily amplified dominant markers (SCoT, ISSR and RAPD) for diagnostic fingerprinting in tetraploid potato. Am J Pot Res 88:226-237

Gulzar B, Mujib A, Rajam MV, Frukh A, Zafar N (2019) Identification of somatic embryogenesis (SE) related proteins through labelfree shotgun proteomic method and cellular role in Catharanthus roseus (L.) G. Don. Plant Cell Tissue Organ Cult 137(2):225-237

Johansen DA (1940) Plant microtechnique. McGraw-Hill Book Co., New York, NY

Kher M, Soner D, Srivastava N, Nataraj M, Teixeira da Silva JA (2016) Micropropagation of Clerodendrum phlomidis L.F. J Hort Res 24(1):21-28

Kirtikar KR, Basu BD (1994) Indian Medicinal Plants. Indian Medicinal Plants, pp 2609-2610

Malik MQ, Mujib A, Gulzar B, Zafar N, Syeed R, Mamgain J, Ejaz B (2020a) Genome size analysis of field grown and somatic embryo regenerated plants in Allium sativum L. J Appl Genet 61:25-35

Malik MQ, Mujib A, Gulzar B, Zafar N, Syeed R, Mamgain J, Ejaz B (2020b) Enrichment of alliin in diferent in vitro grown tissues of Allium sativum through $\mathrm{CdCl}_{2}$ elicitation as revealed by high performance thin layer chromatography (HPTLC). Indus Crops Prod 158:113007

Mujib A (2005) In vitro regeneration of Sandal (Santalum album L.) from leaves. Turk J Bot 29:63-67

Mujib A, Banerjee S, Maqsood M, Ghosh PD (2013) Somatic embryogenesis of some member ornamental genera of Amaryllidaceae and allied families: the similarities and differences. Open Hort J 6:9-18

Mujib A, Tanu AM, Dipti T, Zafar N, Gulzar B (2017) In vitro propagation of Althaea officinalis: the role of plant growth regulators in morphogenesis. Bio Technologia 98(3):167-173

Murashige T, Skoog F (1962) A revised medium for rapid growth and bioassays with tobacco tissue cultures. Physiol Plant 15:473-497

Najwa AH, Soo PK, Sreeramanan S, Bee LC (2021) Regeneration and micropropagation of Meyer lemon (Citrus x meyeri) supported by polymorphism analysis via molecular markers. Sci Hort 286:110225

Nazar S, Hussain MA, Khan A, Muhammad G, Bukhari SN (2020) Alkaloid-rich plant Tylophora indica; current trends in isolation strategies, chemical profiling and medicinal applications. Arab J Chem 13:6348-6365

Niazian M, Noori SAS, Galuszka P, Tohidfar M, Mortazavian SM (2017) Genetic stability of regenerated plants via indirect somatic embryogenesis and indirect shoot regeneration of Carum copticum L. Ind Crops Prod 97:330-337

Pal SP, Alam I, Anisuzzaman M, Sarker KK, Sharmin SA, Alam MF (2007) Indirect organogenesis in summer squash (Cucurbita pepo L.). Turk J Agricult for 31:63-70

Pan B, Fang S, Zhang J, Pan Y, Liu H, Wang Y, Li M, Liu L (2020) Chinese herbal compounds against SARS-CoV-2: puerarin and quercetin impair the binding of viral S-protein to ACE2 receptor. Comp Struc Biotechnol J 18:3518-3527

Raji MR, Farajpour M (2020) Genetic fidelity of regenerated plants via shoot regeneration of muskmelon by inter simple sequence repeat and flow cytometry. J Saudi Soc Agri Sci 20:88-93

Rajput S, Agrawal V (2020) Micropropagation of Atropa acuminata Royle ex Lindl. (a critically endangered medicinal herb) through root callus and evaluation of genetic fidelity, enzymatic and nonenzymatic antioxidant activity of regenerants. Acta Physiol Plant 42:160 
Rathore NS, Rai MK, Phulwaria M, Rathore N, Shekhawat NS (2014) Genetic stability in micropropagated Cleome gynandra revealed by SCoT analysis. Acta Physiol Plant 36:555-559

Rewers M, Drouin J, Kisiala A, Sliwinska E, Cholewa E (2012) In vitro regenerated wetland sedge Eriophorum vaginatum L. is genetically stable. Acta Physiol Plant 34:2197-2206

Rohlf FJ (2005) NTSYSpc (Numerical taxonomy and mutivarate analysis system). Version 2.2. Exeter software. Applied Biostatistics Inc, New York

Sah NK (2017) Scope of plant biotechnology in the developing countries. In: Prasad BD et al (eds) Plant biotechnology, vol 1. Apple Academic Press, Palm Bay, FL, pp 45-66

Sahai A, Shahzad A, Anis M (2010) High frequency plant production via shoot organogenesis and somatic embryo-genesis from callus in Tylophora indica, an endangered plant species. Turk J Bot 34:11-20

Samaddar T, Nath S, Halder M, Sil B, Roychowdhury D, Sen S, Jha S (2012) Karyotype analysis of three important traditional Indian medicinal plants, Bacopa monnieri, Tylophora indica and Withania somnifera. The Nucleus 55:17-20

Samarina L, Gvasaliya M, Koninskaya N, Rakhmangulov R, Efremov A, Kiselyova N, Ryndin A, Hanke MV (2019) A comparison of genetic stability in tea [Camellia sinensis (L.) Kuntze] plantlets derived from callus with plantlets from long-term in vitro propagation. Plant Cell Tissue Organ Cult 138:467-474

Sambrook J, Fritsch EF, Maniatis Y (1989) Molecular cloning: a laboratory manual, 2nd edn. Cold Spring Harbor, Cold Spring Harbor Laboratory

Sharma U, Agrawal V (2018) In vitro shoot regeneration and enhanced synthesis of plumbagin in root callus of Plumbago zeylanica L.: an important medicinal herb. In Vitro Cell Dev Biol-Plant 54:423-435

Sharma MM, Verma RN, Singh A (2014) Assessment of clonal fidelity of Tylophora indica (Burm. F.) Merrill "in vitro" plantlets by ISSR molecular markers. Springer plus. https://doi.org/10.1186/ 2193-1801-3-400

Sharmin SA, Alam MJ, Sheikh MMI, Sarker KK, Khalekuzzaman M, Haque MA, Alam MF, Alam F (2014) Somatic embryogenesis and plant regeneration in Wedelia calendulacea Less. An endangered medicinal plant. Braz Arch Biol Technol 57(3):394-401

Sneath PHA, Sokal RR (1973) Numerical taxonomy. W H Freeman, San Francisco
Soni V, Bhusan M, Swarnkar PL (2015) Biotechnological approaches for conservation of Tylophora indica: an economically important endangered medicinal plant. Economol J 5:2-5

Syeed R, Mujib A, Malik MQ, Mamgain J, Ejaz B, Gulzar B, Zafar N (2021) Mass propagation through direct and indirect organogenesis in three species of genus Zephyranthes and ploidy assessment of regenerants through flow cytometry. Mol Biol Rep 48:513-526

Tahir SM, Victor K, Abdulkadir S (2011) The effect of 2, 4- Dichlorophenoxy acetic acid (2, 4-D) concentration on callus induction in sugarcane (Saccharum officinarum). Niger J Basic Appl Sci 9(2):213-217

Teixeira da Silva JA, Jha S (2016) Micropropagation and genetic transformation of Tylophora indica (Burm. F.) Merr.: a review. Plant Cell Rep 35(11):2207-2225

Von Arnold S, Sabala I, Bozhkov P, Dyachok JA, Filonova L (2002) Developmental pathways of somatic embryogenesis. Plant Cell Tissue Organ Cult 69:233-249

Wernicke W, Milkovits L (1986) Development gradient in wheat leaves. Responses of leaf segments in different genotypes cultured in vitro. J Plant Physiol 115:49-58

Yang JL, Niu YD, Yang CP, Liu GF, Li CH (2011) Induction of somatic embryogenesis from female flower buds of elite Schisandra chinensis. Plant Cell Tissue Organ Cult 106:391-399

You CR, Fan TJ, Gong XQ, Bian FH, Liang LK, Qu FN (2011) A high- frequency cyclic secondary somatic embryogenesis system for Cyclamen persicum Mill. Plant Cell Tissue Organ Cult 107:233-242

Zafar N, Mujib A, Ali M, Tonk D, Gulzar B, Malik M, Syeed R, Mamgain J (2019) Genome size analysis of field grown and tissue culture regenerated Rauvolfia serpentina (L) by flow cytometry: histology and scanning electron microscopic study for in vitro morphogenesis. Ind Crops Prod 128:545-555

Zhang CX, Li Q, Kong L (2007) Induction, development and maturation of somatic embryos in Bunge's pine (Pinus bungeana Zucc. ex Endl.). Plant Cell Tissue Organ Cult 91:273-280

Publisher's Note Springer Nature remains neutral with regard to jurisdictional claims in published maps and institutional affiliations. 